\title{
Speckle tracking echocardiography - a new tool for quantification of myocardial function*
}

\author{
Jaroslav Meluzín, Helena Podroužková, Martin Pešl, \\ Pavel Leinveber, Marek Orban \\ $1^{\text {st }}$ Dept of Internal Medicine/Cardioangiology, St. Anna Hospital, Brno, Czech Republic
}

\begin{abstract}
Meluzín J, Podroužková H, Pešl M, Leinveber P, Orban M (1 ${ }^{\text {st }}$ Dept of Internal Medicine/Cardioangiology, St. Anna Hospital, Brno, Czech Republic). Speckle tracking echocardiography - a new tool for quantification of myocardial function. Cor Vasa 2008;50(1):28-33.
\end{abstract}

The aim of this paper is to provide a summary of the current knowledge of a new echocardiographic method - speckle tracking echocardiography. Speckle tracking echocardiography (STE) allows frame-to-frame tracking of acoustic markers (speckles) in 2-dimensional echocardiographic images. Based on relative changes in speckle position, the method enables simultaneous quantification of myocardial deformation in 2 dimensions. Such speckle tracking is direction-independent. Using various echocardiographic views, STE allows quantifying longitudinal, circumferential, and radial strain, and strain rate in all myocardial segments. In addition, the method can be utilized to assess myocardial torsion as a difference between the apical and basal rotation of the left ventricle. To date, STE has been successfully used to quantify regional and global left ventricular function, to detect myocardial ischemia, to assess asynchrony of the left ventricular contraction, and to differentiate between subendocardial and transmural myocardial infarction. In experimental settings, it was found to provide exact information on myocardial viability. However, studies using STE are still few in number. Thus, further projects are necessary to definitely determine the role of this method in clinical practice.

Key words: Speckle tracking echocardiography - Myocardial function - Strain

Meluzín J, Podroužková H, Pešl M, Leinveber P, Orban M (I. interní kardioangiologická klinika, Fakultní nemocnice u sv. Anny, Brno, Česká republika). „Speckle tracking“ echokardiografie - nová metoda kvantifikace funkce myokardu. Cor Vasa 2008;50(1):28-33.

Cílem této práce bylo shrnout současné znalosti o nové echokardiografické metodě nazvané „speckle tracking“ (volně přeloženo „Sledování myokardiálního bodu“). Speckle tracking echokardiografie (STE) umožňuje během provádění dvourozměrné echokardiografie sledovat mezi jednotlivými časovými záběry myokardu polohu jednotlivých „skvrn-bodů“ ve struktuře myokardu. Na základě vzájemných změn poloh těchto „skvrn-bodů“ mezi jednotlivými záběry STE dovoluje současně kvantifikovat deformaci myokardu ve dvou rozměrech. Metoda je úhlově nezávislá. STE dovoluje při užití rủzných echokardiografických pohledů kvantifikovat podélnou (longitudinální), obvodovou (circumferenciální) a radiální deformaci a rychlost deformace ve všech myokardiálních segmentech. Metoda může být navíc využita k posouzení „zkrouceni“ (torze) myokardu, což je rozdíl mezi rotací srdečního hrotu a srdeční báze levé komory. Do současnosti byla STE úspěšně použita ke kvantifikaci regionální a globální funkce levé komory, k průkazu ischemie myokardu, k posouzení asynchronie kontrakce levé komory a k rozlišení mezi subendokardiálním a transmurálním infarktem myokardu. $\mathrm{V}$ experimentu metoda poskytla přesnou informaci o viabilitě myokardu. Nicméně studií o STE je zatím málo. Proto je potřeba provést další projekty, aby bylo možno definitivně posoudit úlohu této metody v klinické praxi.

Klíčová slova: Speckle tracking echokardiografie - Myokardiální funkce - Deformace

Address: prof. MUDr. Jaroslav Meluzín, CSc., FESC, 1st Dept of Internal Medicine/Cardioangiology, St. Anna Hospital, Pekařská 53, 65691 Brno, Czech Republic, e-mail: jaroslav.meluzin@fnusa.cz

\section{INTRODUCTION}

The exact quantitative evaluation of the regional left ventricular (LV) function still represents a great challenge. In this regard, all echocardiographic methods utilized thus far have important limitations which hamper their widespread clinical application. In addi- tion, myocardial contraction is a very complex process implying 3-dimensional deformation (longitudinal, circumferential, and radial) as well as basal and apical rotation creating myocardial torsion (twist). At present, no echocardiographic method is able to analyze all these components accounting for the global myocardial performance. In this paper, we

*The work was supported in part by a grant of the Ministry of Education of the Czech Republic (MSM, No. 0021622402). 
would like to discuss a new echocardiographic method - speckle tracking echocardiography, which offers a new insight into this area of problems.

\section{PRINCIPLES OF THE METHOD}

Speckle tracking echocardiography (STE) allows frame-to-frame tracking of acoustic markers (speckles) in 2-dimensional (2-D) echocardiographic images. These speckles are normally visible in the myocardium using 2-D echocardiography and are the consequence of the interference of the reflected ultrasound causing an irregular speckled pattern of the myocardium (Figure 1). Each region of the myocar-

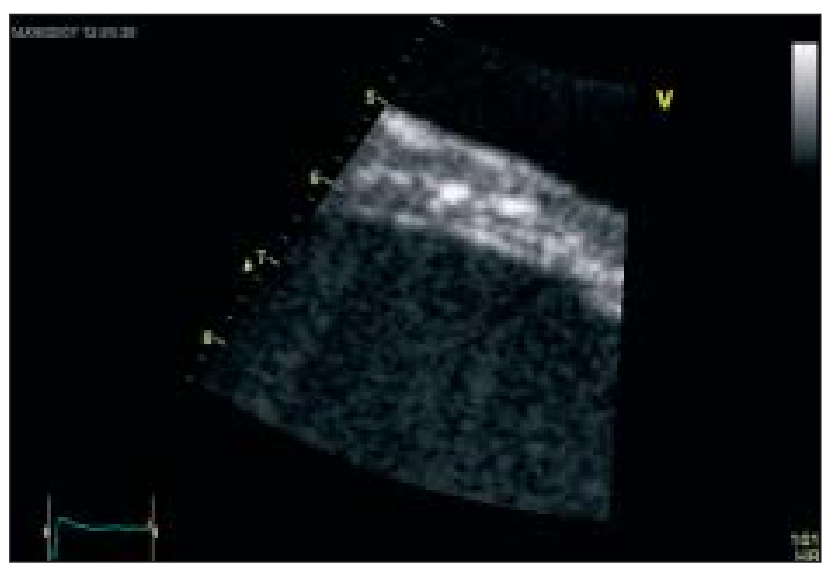

Figure 1 Acoustic markers (speckles) in 2-D echocardiographic image. Detail of the middle part of the septum.

Speckles are normally visible in the myocardium using 2-D echocardiography. They are the consequence of the interference of the reflected ultrasound causing irregular speckled pattern of the myocardium. Speckle tracking echocardiography allows evaluation of myocardial deformation based on frame-to-frame tracking of these speckles.

dium has its own unique pattern of speckles that follows myocardial motion and can be recognized in a subsequent frame. The relative changes in the position of speckles from frame to frame enable quantification of myocardial deformation in 2 dimensions. Such speckle tracking is direction-independent.

\section{DATA ACQUISITION}

Parasternal short-axis views are used for the evaluation of circumferential and radial strains or strain rates as well as for the assessment of basal and apical rotation. Apical views are utilized to determine longitudinal and transverse strains and strain rates. Individual views are stored in cineloop format for the subsequent off-line computer analysis. Special software (Echopack PC, GE Healthcare, Horten, Norway) is commercially available for this purpose. In each view analyzed, the endocardial border is manually traced in the endsystole. Then, the software automatically depicts the endocardial and epicardial borders of the LV wall and divides the myocardium into 6 equidistant segments. Finally, the software calculates the mean values of the desired parameters (strain, strain rate, rotation) for the entire myocardium of each segment. The curves defining the time course of myo-

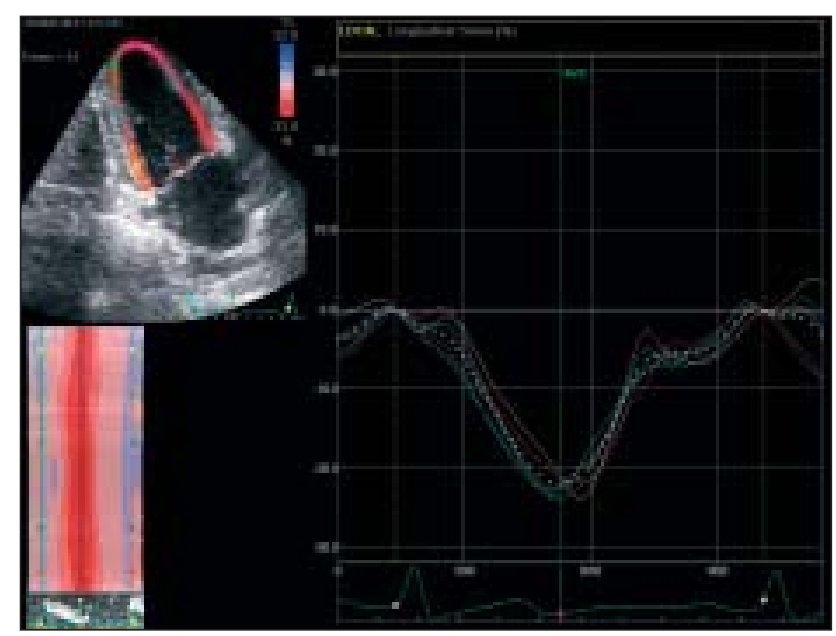

Figure 2 Evaluation of regional strain using STE

Longitudinal strain derived from STE in a healthy volunteer. Each colored curve represents the average of one segment (6 curves describe 6 segments). The segments are designated by various colors in the upper left corner of the picture. Regional peak systolic, endsystolic, or postsystolic strain can be quantified. The white dotted line represents the average of all 6 segmental curves.

cardial deformation or rotation are created by software for each segment for analysis of individual parameters (peak systolic or endsystolic strain, peak systolic strain rate, peak early and late diastolic strain rates, peak systolic rotation, time to peak rotation, rotational velocity, etc.). In addition, the latest Echopack versions automatically create a curve averaging the individual curves of all in-plane segments (Figure 2, dotted line). It allows rapid determination of the mean (i.e. global) functional parameters in the analyzed plane. The averaging of curves is especially important in patients with contractile asynchrony, in whom peaks of deformation (or rotation) do not occur at the same time. In such a situation, the instantaneous global deformation (or rotation) is smaller than the sum of peak values divided by the number of segments. The advantage of the software is its ability to transfer the time intervals gained during the preceding analysis of Doppler flows into the views with final regional curves. By defining the times of aortic valve opening and closure and mitral valve opening, one can get exact information on peak systolic, endsystolic, and postsystolic values of individual parameters.

The success rate of 2-D strain analysis is relatively high. Leitman et al. ${ }^{(1)}$ demonstrated that $80.3 \%$ of infarct and $97.8 \%$ of normal segments can be adequately tracked using this technique. Serri et al. ${ }^{(2)}$ was able to analyze 2 -D strain in $94.4 \%$ of normal segments and $94.8 \%$ of segments in patients with hypertrophic cardiomyopathy. Interobserver and intraobserver variabilities for longitudinal, circumferential, and radial strain were $7.5 \%, 10 \%, 13.5 \%$ and $7.9 \%, 10.9 \%$, and $12.5 \%$, respectively. ${ }^{(2)}$ In direct comparison of interobserver and intraobserver variabilities for longitudinal strain, 2-D strain values were found to have markedly lower variabilities $(7.5 \%$ and $7.9 \%$ ) than the strain values derived from Doppler tissue imaging (13.7\% and $14.5 \%$, respectively). 


\section{COMPARISON WITH SOME OTHER NEW ECHOCARDIOGRAPHIC METHODS ASSESSING REGIONAL LV FUNCTION. ADVANTAGES AND LIMITATIONS OF STE}

Doppler tissue imaging (DTI) or DTI-derived strain or strain rate measurements that have been most commonly used to evaluate regional myocardial function have several limitations. DTI-derived parameters are angle-dependent. It means that only components of motion parallel to the ultrasound beam can be exactly measured. In addition to myocardial function, DTI velocities are also influenced by other factors that are not associated with myocardial performance (extracardiac motion due to respiration, translational motion as found for example in right ventricular overload, etc.). Due to the tethering of normokinetic myocardium, the adjacent segments with no myocardial deformation (akinesis) show motion mimicking the preserved myocardial function. DTI-derived strain and strain rate represent a further step in an effort to achieve quantitative information on LV regional systolic and diastolic function. They reflect local intensity (strain) and velocity (strain rate) of myocardial deformation. Even if they are less influenced by the tethering effect and reflect more exactly the real myocardial function, they are still angle-dependent. It means that myocardial function cannot be determined in all myocardial segments (mainly apical segments are excluded from the analysis). In addition, only longitudinal myocardial function can be determined in the majority of LV segments, while the circumferential and radial components of LV function can be evaluated in only very limited areas of the left ventricle.

As compared with these methods, STE possesses several important advantages. It is independent of transducer orientation. It means that myocardial function and the course of myocardial deformation can be quantified and expressed in all the segments. The imaging of one 2-D view allows to gain functional parameters in 2 orthogonal dimensions implying that one is able to express simultaneously either circumferential and radial (when using parasternal short-axis views) or longitudinal and transverse myocardial deformation (when using apical long-axis views).

There are also several limitations of STE. At present, the optimal frame rate for speckle tracking is around $70 \mathrm{fps}$. Thus, the method has a somewhat lower time resolution. It may slightly underestimate the peak values (mainly in the strain rate evaluation) and the assessment of myocardial synchrony may not follow the small time differences (below approximately $10-15 \mathrm{~ms}$ ). STE is derived from 2-D imaging. It means that the quality of STE is dependent on the quality of 2-D images. Acquiring quantitative data requires off-line computer analysis and is relatively time-consuming (analysis takes 10-120 min according to the number of parameters evaluated and the number of cycles analyzed).

\section{POTENTIAL CLINICAL APPLICATIONS OF STE}

\section{A. Myocardial fibre architecture and myocardial function}

Myocytes and myocardial fibre orientation in the left ventricle vary. Myocardial fibres run circumferen- tially at the mid-wall. ${ }^{(3)}$ In the epicardium, they rotate clockwise (as viewed from the outside) to form a $-60^{\circ}$ left-handed helix. In the endocardium, they rotate counterclockwise to create a $+60^{\circ}$ right-handed helix. ${ }^{(4)}$ Analyzing the subendocardial region, Greenbaum et al. ${ }^{(3)}$ described longitudinally directed fibres forming the trabeculae and papillary muscles, while fibres deep to and between the trabeculae coursed obliquely. Most models studying the global LV myocardial architecture suppose that the right-handed helical geometry in the subendocardium gradually changes into a left-handed geometry in the subepicardium. ${ }^{(3,5)}$ This setting of myocardial fibres accounts for the complex 3-dimensional deformation of the left ventricle, which has several components: longitudinal and circumferential deformation (systolic shortening, diastolic lengthening), radial deformation (systolic thickening, diastolic thinning), and the LV basal and apical rotation creating myocardial torsion (twist). STE is the first echocardiographic method allowing to assess and quantify all these components.

\section{B. Quantification of regional \\ and global myocardial function}

STE provides parameters quantifying both regional and global systolic and diastolic functions. These parameters are derived from the magnitude (strain) and velocity (strain rate) of myocardial deformation. The theoretical background, definition, and the clinical meaning of strain and strain rate analysis have already been published in detail previously. ${ }^{(6-8)}$ In each echocardiographic view analyzed, STE allows to determine simultaneously peak systolic strains in all segments recorded reflecting the regional systolic function of individual segments. The sum of peak values from all LV segments divided by the number of segments analyzed gives the global LV systolic performance index (global LV strain). Analogically, peak systolic, early and late diastolic strain rate values can be determined in each segment and the mean value can be calculated. The strain is negative for myocardial shortening and positive for myocardial lengthening.

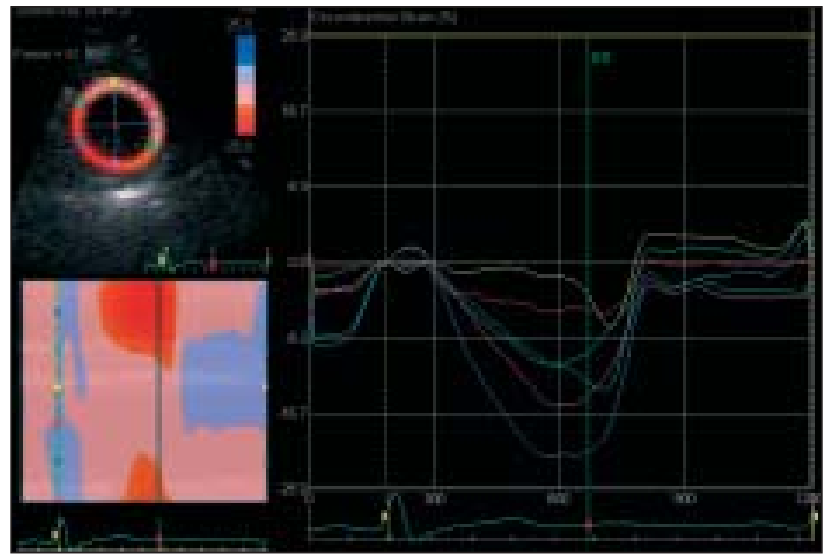

Figure 3 Strain during acute ischemia

This figure demonstrates acute ischemia during short-term angioplasty balloon inflation in the left anterior descending coronary artery. There is a clear lack of systolic deformation with postsystolic deformation in the ischemic anteroseptal and anterior regions. 
STE has repeatedly been shown to provide accurate and angle-independent strain values as validated against sonomicrometry or tagged magnetic resonance imaging. ${ }^{(9-12)}$ Two-dimensional strain can be clinically utilized to detect regional systolic dysfunction in patients with myocardial infarction ${ }^{(1)}$ or during acute and exercise-induced myocardial ischemia. ${ }^{(13,14)}$ Figure 3 demonstrates acute myocardial ischemia during short-term angioplasty balloon inflation in the left anterior descending coronary artery. There is a clear lack of systolic deformation with postsystolic thickening (deformation) in the ischemic anteroseptal region. Becker et al. ${ }^{(15)}$ demonstrated that segments defined as normokinetic, hypokinetic, and akinetic by magnetic resonance imaging can be distinguished by strain and strain rate parameters. Peak systolic radial strain allowed detection of dyssynergy with a sensitivity and a specificity of $83.5 \%$ (cut-off value $29.1 \%$ ). The same parameter discriminated akinesis from hypokinesis with a sensitivity of $82.7 \%$ and a specificity of $94.5 \%$ (cut-off value $21 \%$ ). Peak systolic radial strain and peak systolic circumferential strain were more accurate than peak systolic radial and circumferential strain rates in the detection of dyssynergy defined by magnetic resonance imaging. Thus, strain values are likely to be optimal parameters for the quantification of the severity of $\mathrm{LV}$ dysfunction.

Analysis of individual components of LV systolic function with STE may provide more sensitive information than commonly clinically utilized global parameters such as LV ejection fraction. As compared with healthy controls, Serri et al. ${ }^{(2)}$ described a significant worsening of basal, middle, and apical longitudinal strain in patients with non-obstructive hypertrophic cardiomyopathy having excellent mean LV ejection fraction of $69.3 \%$. It supports the idea of clinical importance of the quantification of longitudinal myocardial contraction to unmask a subnormal LV systolic function. ${ }^{(16,17)}$

Another potential clinical application of 2-D deformation analysis is the differentiation of subendocardial and transmural myocardial infarction ${ }^{(18)}$ and evaluation of myocardial viability. ${ }^{(19)}$ In subendocardial infarction, 2-D circumferential strain parameters are normal but longitudinal strain parameters are reduced. In contrast, transmural infarctions have both short-axis and long-axis 2-D strain parameters reduced. ${ }^{(18)}$ Similar results were obtained by Becker et al., ${ }^{(20)}$ who described the ability of deformation parameters derived from STE to discriminate between different transmurality states of myocardial infarction. The radial strain was $27.7 \%, 20.5 \%$, and $11.6 \%$ for segments with no infarction, non-transmural infarction, and transmural infarction, respectively. This parameter allowed distinction between non-transmural and transmural infarction with a sensitivity of $70 \%$ and a specificity of $71 \%$ (cut-off value for radial strain $16.5 \%)$. In a rat experimental model, Migrino et al. ${ }^{(19)}$ demonstrated that 2-D echocardiography using endsystolic circumferential and radial strain is useful for identifying viable/noninfarcted versus nonviable/infarcted myocardium. In this study, the presence of nonviability was verified histologically using triphenyl tetrazolium chloride (TTC) staining. However, when evaluating and quantifying LV function, one has to take into account the fact that deformation parameters are preload-dependent and afterload-dependent. ${ }^{(21)}$

\section{Evaluation of myocardial rotation and torsion (twist)}

During myocardial contraction, the left-handed epicardial fibre helix pulls the apex counterclockwise (as viewed from the apex) and the base clockwise. The right-handed helix in the endocardium does the opposite (Figures 4, 5). However, because of larger radii, the effect of subepicardial fibres predominates.

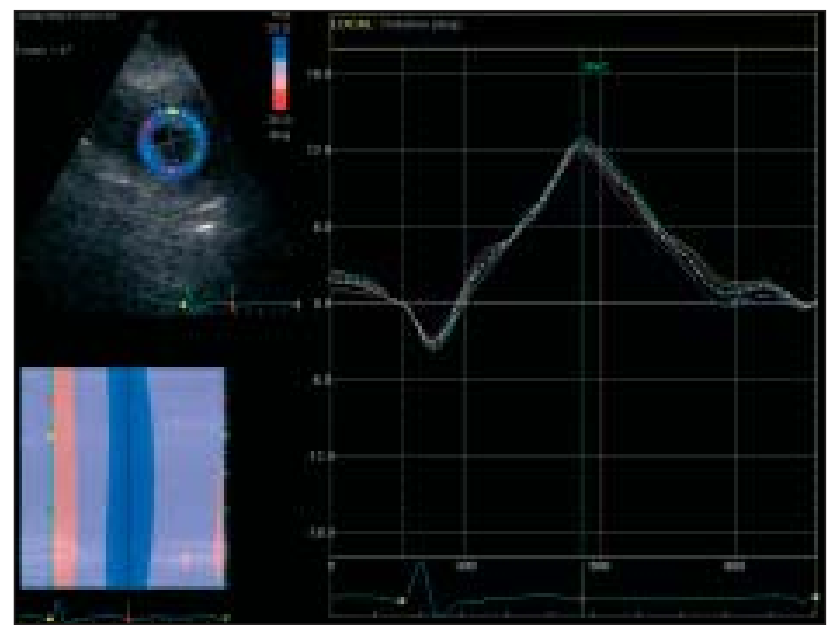

Figure 4 Apical myocardial rotation

During isovolumic contraction (approximately at the time of QRS complex), the LV apex exhibits a short clockwise rotation (negative degrees) induced by the prevailing mechanical activity of right-handed helical fibres in the subendocardium. During ejection, apical rotation changes to counterclockwise (positive degrees) because the left-handed helical subepicardial fibre contraction dominates. The normal segmental curves (in various colors) and a mean curve (white dotted line) in a healthy volunteer.

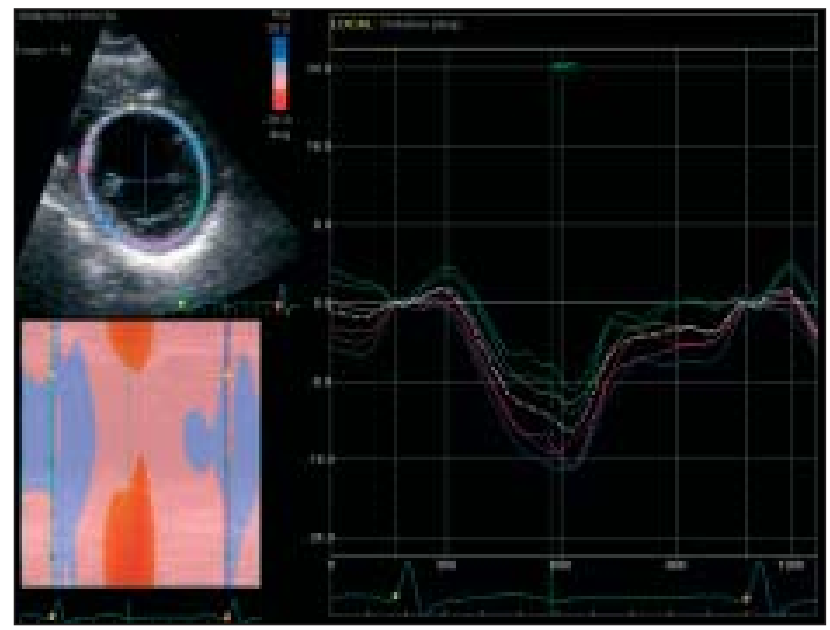

Figure 5 Basal myocardial rotation

At the base, there is a short counterclockwise rotation during isovolumic contraction that is caused by the contraction of subendocardial fibres. During ejection, clockwise rotation follows due to the domination of subepicardial fibre contraction. The normal curves in a healthy volunteer. 
The result is LV torsion (calculated as the difference between the apical and basal rotation of the heart). Torsion (twist) results in storing elastic energy during the systole. During isovolumic relaxation, this energy is abruptly released (elastic recoil) leading to LV diastolic untwisting. Rapid untwisting generates an intraventricular pressure gradient ${ }^{(22)}$ which allows LV filling at low filling pressure (diastolic suction). Through such a mechanism, LV systolic function directly affects the LV filling, i.e. the LV diastolic function. ${ }^{(23,24)}$ Rothfeld et al. ${ }^{(23)}$ found a strong correlation of the magnitude of the ventricular twist with acceleration of the mitral $\mathrm{E}$-wave $(\mathrm{r}=0.75)$ and with mitral E-wave acceleration time $(r=-0.83)$.

STE is an accurate noninvasive method to measure LV torsion. ${ }^{(25,26)}$ The detailed methodology of the analysis of myocardial rotation and torsion using STE has been described elsewhere. ${ }^{(25)}$ From the clinical point of view, it is important that apical rotation and LV twist may serve as important parameters of LV systolic function. ${ }^{(27,28)}$ Takeuchi et al. ${ }^{(28)}$ found a significant decrease in the peak LV twist in patients with chronic anterior myocardial infarction having the LV ejection fraction $<45 \%$, mainly because of the reduced apical rotation. There was a significant correlation between the peak twist and LV ejection fraction $(r=0.73)$ and $L V$ end-systolic volume $(\mathrm{r}=0.56)$. Kroeker et $\mathrm{al}^{\left({ }^{(29)}\right.}$ and Helle-Valle et al. ${ }^{(26)}$ described significant changes in apex rotation during experimental acute ischemia. Occlusion of the left anterior descending coronary artery results in a significant reduction of apical rotation.

\section{Assessment of the synchrony of $L V$ contraction}

Despite significant progress in the methodology of cardiac resynchronisation therapy (CRT) using biventricular stimulation, approximately 30\% of patients with heart failure, who fulfil the current indication criteria for CRT, do not respond to this mode of treatment. Suboptimal patient selection (inclusion of patients with only mild mechanical contractile asynchrony, those with significant coronary artery disease) and technical limitations (impossibility of locating LV lead into the optimal position) may explain such results. In this regard, STE offers 2 types of information which can improve the results of CRT. First, it has the potential to optimize quantification of LV contractile asynchrony, which can be utilized for better selection of candidates suitable for this mode of therapy. In contrast to other echocardiographic methods utilized thus far (M-mode, Doppler tissue imaging, strain and strain rate derived from Doppler tissue imaging), STE allows timing of myocardial deformation of all LV segments including the apical segments, which are not amenable by the aforementioned techniques. The degree of mechanical asynchrony can be simply calculated as the time interval between segments with the earliest and the latest onset or peak of myocardial deformation. Second, the identification of the area of the latest mechanical activation may allow insertion of the LV lead into this area. The LV lead position in the area of the latest contraction deter- mined prior to CRT assures the maximal effect of CRT. ${ }^{(30)}$ Becker et al. ${ }^{\left({ }^{30}\right)}$ successfully used circumferential strain curves derived from the speckle tracking technique from all myocardial segments to describe the temporal course of LV contraction. These authors demonstrated that the segment with the latest peak systolic circumferential strain is the optimal target for the location of LV lead. Such LV lead position results in the greatest reduction in LV volumes and the maximal increase in LV ejection fraction at both 3- and 10-month follow-up. The intraobserver and interobserver variabilities for the determination of time-to-peak circumferential strain are 5.5\% and 9\%, respectively. Figure 6 demonstrates a significant segmental contractile asynchrony in a patient with dilated cardiomyopathy.

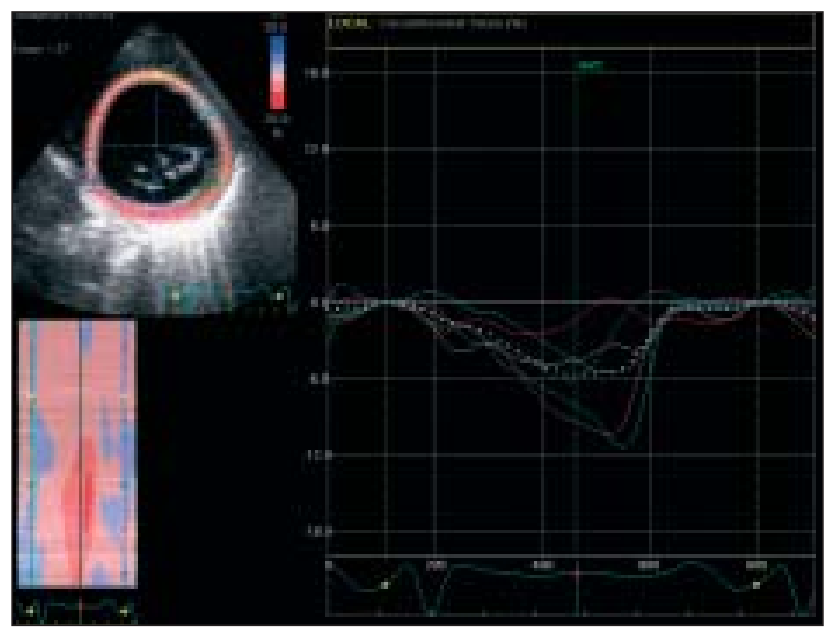

Figure 6 Significant segmental contractile asynchrony in a patient with dilated cardiomyopathy

There are significant differences in times of the peak circumferential strain in individual segments. Mechanical asynchrony can be determined as the time interval between segments with the earliest (septum, red line) and the latest (lateral segment, green line) peak strains. In addition, there is a marked heterogeneity of segmental peak circumferential strain values, which are significantly depressed with postsystolic peaks in anterior (light blue line), lateral (green line), and posterior (violet line) segments.

\section{CONCLUSION}

STE appears to be a promising method of evaluating systolic and diastolic myocardial function. It allows quantification of various components of myocardial function, such as longitudinal, circumferential, and radial deformation as well as basal and apical rotation. The difference in the apical and basal LV rotation defines the myocardial torsion that significantly contributes to normal systolic and diastolic LV function. In addition, STE enables quantification of the onset and peak of mechanical activation of all myocardial segments, which can be utilised to improve the current methodology of resynchronisation therapy. However, the studies on STE are still few in number and have included only a limited number of patients. Thus, further studies are necessary to definitely determine the role of this method in clinical practice. 


\section{REFERENCES}

1. Leitman M, Lysyansky P, Sidenko S, et al. Two-dimensional strain - A novel software for real time quantitative echocardiographic assessment of myocardial function. J Am Soc Echocardiogr 2004;17:1021-9.

2. Serri K, Reant P, Lafitte M, et al. Global and regional myocardial function quantification by two-dimensional strain. J Am Coll Cardiol 2006;47:1175-81.

3. Greenbaum RA, Ho SY, Gibson DG, Becker AE, Anderson RH. Left ventricular fibre architecture in man. Br Heart J 1981;45:248-63.

4. Thomas JD, Popovic ZB. Assessment of left ventricular function by cardiac ultrasound. J Am Coll Cardiol 2006;48:2012-25.

5. Sengupta PP, Korinek J, Belohlavek M, et al. Left ventricular structure and function. J Am Coll Cardiol 2006;48:1988-2001.

6. Meluzín J, Panovský R, Kincl L. The role of strain and strain rate imaging in the assessment of regional myocardial function. Cor Vasa 2005;47:51-7.

7. Voigt JU, Arnold MF, Karlsson M, et al. Assessment of regional longitudinal myocardial strain rate derived from Doppler myocardial imaging indexes in normal and infarcted myocardium. J Am Soc Echocardiogr 2000; 13:588-98.

8. Stoylen A, Heimdal A, Bjornstad K, et al. Strain rate imaging by ultrasonography in the diagnosis of coronary artery disease. J Am Soc Echocardiogr 2000;13: 1053-64.

9. Amundsen BH, Helle-Valle T, Edvardsen $\mathrm{T}$, et al. Noninvasive myocardial strain measurement by speckle tracking echocardiography. J Am Coll Cardiol 2006;47: 789-93.

10. Langeland S, D'hooge J, Wouters PF, et al. Experimental validation of a new ultrasound method for the simultaneous assessment of radial and longitudinal myocardial deformation independent of insonation angle. Circulation 2005; 112:2157-62.

11. Korinek J, Kjaergaard J, Sengupta PP, et al. High spatial resolution speckle tracking improves accuracy of 2-dimensional strain measurements: An update on a new method in functional echocardiography. J Am Soc Echocardiogr 2007;20:165-70.

12. Korinek J, Wang J, Sengupta PP, et al. Two-dimensional strain - A Doppler-independent ultrasound method for quantitation of regional deformation: Validation in vitro and in vivo. J Am Soc Echocardiogr 2005;18:1247-53.

13. Sun JP, Niu J, Chou D, et al. Alterations of regional myocardial function in a swine model of myocardial infarction assessed by echocardiographic 2-dimensional strain rate imaging. J Am Soc Echocardiogr 2007; 20:498-504.

14. Hanekom L, Cho GY, Leano R, Jeffriess L, Marwick TH. Comparison of two-dimensional speckle and tissue Doppler strain measurement during dobutamine stress echocardiography: an angiographic correlation. Eur Heart J 2007;28:1765-72.

15. Becker M, Bilke E, Kuhl H, et al. Analysis of myocardial deformation based on pixel tracking in two dimensional echocardiographic images enables quantitative assessment of regional left ventricular function. Heart 2006; 92:1102-8.

16. Paraskevaidis IA, Tsiapras D, Kyrzopoulos S, et al. The role of left ventricular long-axis contraction in patients with asymptomatic aortic regurgitation. J Am Soc Echocardiogr 2006;19:249-54.

17. Dogan S, Aydin M, Gursurer M, Dursun A, Onuk T, Madak H. Prediction of subclinical left ventricular dysfunction with strain rate imaging in patients with mild to moderate rheumatic mitral stenosis. J Am Soc Echocardiogr 2006;19:243-8.

18. Chan J, Hanekom L, Wong Ch, Leano R, Cho GY, Marwick TH. Differentiation of subendocardial and transmural infarction using two-dimensional strain rate imaging to assess short-axis and long-axis myocardial function. J Am Coll Cardiol 2006;48:2026-33.

19. Migrino R, Zhu X, Pajewski N, Brahmbhatt T, Hoffmann R, Zhao M. Assessment of segmental myocardial viability using regional 2-dimensional strain echocardiography. J Am Soc Echocardiogr 2007;20:342-351

20. Becker M, Hoffmann R, Kuhl H, et al. Analysis of myocardial deformation based on ultrasonic pixel tracking to determine transmurality in chronic myocardial infarction. Eur Heart J 2006;27:2560-6.

21. Becker M, Kramann R, Dohmen G, et al. Impact of left ventricular loading conditions on myocardial deformation parameters: Analysis of early and late changes of myocardial deformation parameters after aortic valve replacement. J Am Soc Echocardiogr 2007;20:681-9.

22. Notomi Y, Martin-Miklovic MG, Oryszak SJ, et al Enhanced ventricular untwisting during exercise. A mechanistic manifestation of elastic recoil described by Doppler tissue imaging. Circulation 2006;113:2524-33.

23. Rothfeld JM, LeWinter MM, Tischler MD. Left ventricula systolic torsion and early diastolic filling by echocardiography in normal humans. Am J Cardiol 1998;81: 1465-9.

24. Bell SP, Nyland L, Tischler MD, McNabb M, Granzier H, LeWinter MM. Alterations in the determinants of diastolic suction during pacing tachycardia. Circ Res 2000;87:235-40.

25. Notomi Y, Lysyansky P, Setser RM, et al. Measurement of ventricular torsion by two-dimensional ultrasound speckle tracking imaging. J Am Coll Cardiol 2005 45:2034-41.

26. Helle-Valle T, Crosby J, Edvardsen T, et al. New noninvasive method for assessment of left ventricular rotation. Speckle tracking echocardiography. Circulation 2005; 112:3149-56.

27. Kim HK, Sohn DW, Lee SE, et al. Assessment of left ventricular rotation and torsion with two-dimensional speckle tracking echocardiography. J Am Soc Echocardiogr 2007;20:45-53.

28. Takeuchi M, Nishikage T, Nakai H, Kokumai M, Otani $\mathrm{S}$, Lang RM. The assessment of left ventricular twist in anterior wall myocardial infarction using two-dimensional speckle tracking imaging. J Am Soc Echocardiogr 2007 20:36-44.

29. Kroeker CAG, Tyberg JV, Beyar R. Effects of ischemia on left ventricular apex rotation. Circulation 1995;92: 3539-48.

30. Becker M, Kramann R, Franke A, et al. Impact of left ventricular lead position in cardiac resynchronisation therapy on left ventricular remodelling. A circumferential strain analysis based on 2D echocardiography. Eur Heart J 2007;28:1211-20.

Received 29 August 2007

Revision accepted 11 October 2007 